\title{
Examination of polychlorinated dibenzo-p-dioxins and polychlorinated dibenzofurans in process water of kraft pulp bleaching mill using chlorine dioxide from the aspect of environmental water quality
}

Received: August 30, 2002 / Accepted: December 2, 2002

\begin{abstract}
Process water of a pulp mill with extended kraft cooking, two-stage oxygen delignification, and chlorine dioxide bleaching was examined from the aspect of a new standard for environmental water quality in Japan. According to the new standard, the concentration of dioxins - polychlorinated dibenzo- $p$-dioxins, polychlorinated dibenzofurans, coplanar polychlorinated biphenyls - in environmental water is restricted to less than $1 \mathrm{pg} T E Q / 1$. We clarified that the concentrations of the dioxins in sewers in the chlorine dioxide stage and the alkali stage were less than $1 \mathrm{pg}$ TEQ/1 and that the 2,3,7,8-tetrachlorodibenzofuran concentrations were $0.5 \mathrm{pg} / 1$ or less. In addition, a main source of 1,3,6,8- and 1,3,7,9-tetrachlorodibenzo- $p$-dioxins in the process water seemed to be an agrochemical in water supplied from a river.
\end{abstract}

Key words Kraft pulp • Bleaching - Chlorine dioxide • Polychlorinated dibenzo- $p$-dioxins · Polychlorinated dibenzofurans

\section{Introduction}

During the 1980s the fact that chlorine used for pulp bleaching is connected to the release of dioxins ${ }^{1}$ and chloroform ${ }^{2}$ into the environment was proven in Canada and other countries. Since that time, each papermaking company has been implementing a variety of policies designed to reduce dioxin generation. The law concerning special measures against dioxins took effect in Japan on January 15, 2000.

K. Nakamata

Hokuetsu Paper Mills, Technical and Development Division, Tokyo 103-0022, Japan

H. Ohi $(\bowtie)$

Institute of Agricultural and Forest Engineering, University of

Tsukuba, Tsukuba 305-8572, Japan

Tel. +81-298-53-4639; Fax +81-298-55-2203

e-mail: ohihiros@sakura.cc.tsukuba.ac.jp
According to the new law, "kraft pulp and sulfite pulp bleaching facilities that use chlorinated bleaching agents as well as chlorine" are specified as "designated and waterquality related facilities that generate dioxins." The law established that the level of environmental water quality the environmental standard for dioxins consisting of polychlorinated dibenzo- $p$-dioxins (PCDDs), polychlorinated dibenzofurans (PCDFs), and coplanar polychlorinated biphenyls (PCBs) in rivers, streams, and the sea - is $1 \mathrm{pg}$ $\mathrm{TEQ}^{\mathrm{WHO}}{ }^{\mathrm{W}} / 1$ or less, and that the level of mill effluent for the dioxins is $10 \mathrm{pg} \mathrm{TEQ} \mathrm{TH}^{\mathrm{WHO} 1998} / 1$ or less (i.e., 10 times the environmental standard). Toxic equivalency factors (TEFs) established by the World Health Organization (WHO) in 1998 are used, and the data are converted to the toxic equivalency quantity (TEQ) here.

According to the results from collaborative surveys of 1998 by the Japanese Ministry of the Environment and the Japan Paper Association, the actual concentrations of dioxins in effluent after treated wastewater was released from pulp mills were lower than the environmental standard established in 2000. In other words, the average value was $0.12 \mathrm{pg} \mathrm{TEQ}^{\mathrm{WHO} 1998} / 1$, and a median value was $0.061 \mathrm{pg}$ $\mathrm{TEQ}^{\mathrm{WHO} 1998} / 1$ (0.0021-0.62 pg TEQ ${ }^{\mathrm{WHO} 1998} / 1$ at nine mills $)^{3} \mathrm{In}$ an inventory of dioxin generation of 1998 in Japan, the total amount of dioxins in wastewater from Japanese kraft pulp mills was estimated at only $0.1 \mathrm{~g} \mathrm{TEQ}{ }^{\mathrm{WHO} 1998}$ among the total discharge of 2900-2940g TEQ ${ }^{\mathrm{WHO} 1998}$ per year for all of Japan. $^{4,5}$

There remained questions, discussed in governmental committees and by others, whether the above-cited levels could be maintained in cases where, for example, an excessive amount of chlorine gas would be added to the bleaching process for whatever reason. In addition, the 1999 surveys had shown that the dioxin concentrations of the process water from 16 mills before wastewater treatment were in the range of $0.10-78 \mathrm{pg} \mathrm{TEQ} \mathrm{T}^{\mathrm{WHO} 1998} / 1$. Therefore, kraft pulp bleaching facilities using chlorine were designated under the new law as water quality-related dioxin generation facilities. ${ }^{4,5}$

It is well known that there is a chlorine dioxide-elemental chlorine-free (ECF) bleaching process that uses no chlo- 
rine gas. Surveys and tests performed outside of Japan had already confirmed that almost no dioxins are generated during ECF bleaching. ${ }^{6,7}$ As mentioned previously, however, the pulp bleaching mills that use chlorinated bleaching agents including chlorine dioxide have been specified as the facilities that generate dioxins because of less ECF mill experience and no published data on dioxins in Japan.

On the other hand, it has been shown that the cessation of chlorine gas bleaching resulted in a reduced load of dioxin-like compounds in the recipient water body, ${ }^{8}$ and that no PCDDs and PCDFs were found in any of the bleaching line filtrates of a complete chlorine dioxide-substituted kraft mill. ${ }^{9}$

Historical inputs of dioxins from a pulp mill to a lake were assessed when analyzing the sediment core..$^{10}$ The paper proved that with the construction of the mill in 1965 large quantities of hexachlorodibenzo- $p$-dioxins (HxCDDs), 2,3,7,8-tetrachlorodibenzo- $p$-dioxin (TCDD) and 2,3,7,8-tetrachlorodibenzofuran (TCDF) were released, and that technological changes at the pulp mill effected a drastic reduction in pulp mill dioxins during the 1990 s. ${ }^{10}$

Another study demonstrated that, generally, of all samples of grebes and seaducks collected in 1989, those from the chlorine-bleached kraft pulp mill site were the most contaminated with PCDDs and PCDFs; moreover, by 1992, after changes to new restriction and chlorine dioxide bleaching processes, PCDDs and PCDFs concentrations were substantially lower than those in $1989 .{ }^{11}$

It has been also reported that the mean concentrations of 2,3,7,8-TCDD were significantly higher in eggs collected in 1991 from downstream nests compared to upstream nests near pulp mills in Canada; by 1997, however, concentrations of 2,3,7,8-TCDD and 2,3,7,8-TCDF were significantly lower than in previous years in nests sampled downstream. ${ }^{12}$ These authors have reported that the dominant congeners - 1,2,3,7,8-pentachlorodibenzo- $p$-dioxins (PnCDD), 1,2,3,6,7,8-HxCDD, 2,3,7,8-TCDD, 2,3,7,8TCDF, 1,2,3,7,8,9-HxCDD, 2,3,4,7,8 pentachlorodibenzofurans (PnCDF) - fell markedly during the early 1990s after the pulp mills changed from molecular chlorine bleaching to alternative bleaching technologies and restricted usage of chlorophenolic wood preservatives and antisapstains. ${ }^{13}$

Nevertheless, most published data of surveys and tests in the pulp and paper research had been limited to determining only 2,3,7,8-TCDD and 2,3,7,8-TCDF, where the minimum detection level was usually $10 \mathrm{pg} / \mathrm{l}$, for example, in the minimum level of the U.S. Environmental Protection Agency (EPA) method 1613. ${ }^{7}$ Thus, with setting the environmental standard at $1 \mathrm{pg} \mathrm{TEQ}^{\mathrm{WHO} 1998} / 1$ in Japan, it becomes necessary to perform new surveys and investigations of whether the addition of excessive chlorine dioxide might cause chlorine molecule formation and subsequent dioxin generation.

To deal with the dioxins issue, pulp bleaching mills have taken measures that focused mainly on introducing oxygen delignification prior to the bleaching process and strengthening the wastewater treatment facilities. ECF bleaching has also begun to be introduced.
We investigated the current status of dioxin-generation levels at a kraft pulp and paper mill where new technologies have been introduced for all processes, from wood chip pretreatment and wood cooking through pulp bleaching. Dioxin levels in process sewers were examined from the aspect of environmental water quality. In addition, we demonstrated the influence of the bleaching lines performance on the environment.

\section{Methods}

\section{Mill description}

The mill is an integrated operation with a manufacturing process that goes from pulp to paper. It is situated in the center of a city with a small area $\left(232 \mathrm{~km}^{2}\right)$ and a large population (520000). The mill had two pulp lines with a capacity of 400000 tons/year before construction of an ECF plant. This pulp plant has incorporated extended kraft cooking digestion, two-stage oxygen delignification, and a three-stage bleaching sequence. The new pulp line is running with hardwood bleached kraft pulp (LBKP): 1200 tons/ day (400000 tons/year). One of the old pulp lines was closed. The other pulp line has conventional cooking with oxygen delignification and chlorine bleaching, but the conventional line has been modified from application of chlorine and sodium hypochlorite bleaching to the other ECF line. The mill, then, has a capacity of 600000 tons of ECF bleached hardwood kraft pulp per year available for selfconsumption and a capacity of 800000 tons of coated and printing/writing paper per year. The main wood materials are oak, originating from the southern United States and eucalyptus from western Australia.

Cooking digestion in the new line consists of an extended cooking process with a vapor-phase single vessel. For the extended cooking operation, a washing zone in the digester is also used for cooking. During this process, cooking liquor is charged into the chip-feeding circulation and also charged separately into three points, such as the top-cooking circulation, the bottom-cooking circulation, and the washing circulation of the digester. The temperature of each circulation is raised to cooking level. In general, extended cooking adopts a longer cooking time, and the cooking temperature can then be lowered by as much as $10^{\circ} \mathrm{C}$ compared with conventional cooking.

The brownstock process consists of a pressure diffuser, a knotter-screening, a twin drum press, two-stage medium consistency oxygen delignification (OO), an atmospheric diffuser, and a twin drum press equipped with a displacing washing apparatus. Carry-over $\left(\mathrm{COD}_{\mathrm{cr}}\right)$ to the bleach plant is $6.1-7.7 \mathrm{~kg} /$ ton of pulp.

The basic concepts of the process configuration are (1) decreasing the COD prior to the bleach plant at as low a level as possible; (2) decreasing the raw washwater; and (3) increasing the oxygen delignification efficiency. The new ECF bleaching plant sequence is $\mathrm{D}_{0}-\mathrm{E} / \mathrm{O}$ (or $\left.\mathrm{E} / \mathrm{P}\right)-\mathrm{DnD}$. The $\mathrm{D}_{0}$ stage is chlorine dioxide treatment. The $\mathrm{E} / \mathrm{O}$ or $\mathrm{E} / \mathrm{P}$ stage is alkaline extraction reinforced with oxygen gas or 
Table 1. Conditions for oxygen delignification and bleaching

\begin{tabular}{lrrrrrc}
\hline Parameter & 1st O & 2nd O & $\mathrm{D}_{0}$ & $\mathrm{E} / \mathrm{O}$ & $\mathrm{Dn}$ & $\mathrm{D}$ \\
\hline Temperature $\left({ }^{\circ} \mathrm{C}\right)$ & 80 & 90 & 60 & 58 & 65 & 65 \\
Pulp consistency $(\%)$ & 12 & 12 & 11 & 11 & 11 & 11 \\
Pressure $(\mathrm{kPa})$ & 570 & 530 & - & 250 & - & - \\
Retention time (min) & 20 & 40 & 60 & 60 & 8 & 180
\end{tabular}

Kappa factor for $\mathrm{D}_{0}$ is 0.17

Chlorine dioxide dosage for Dn and $\mathrm{D}$ is $4.5 \mathrm{~kg} /$ ton of pulp

$\mathrm{O}$, oxygen delignification; $\mathrm{D}_{0}$, chlorine dioxide treatment; $\mathrm{E} / \mathrm{O}$, alkaline extraction reinforced with oxygen; Dn, chlorine dioxide treatment; $\mathrm{D}$, final stage of chlorine dioxide treatment

hydrogen peroxide, respectively. Dn represents chlorine dioxide treatment in a short retention tube, where a small amount of $\mathrm{ClO}_{2}$ is charged and then neutralized with caustic soda prior to the final D stage. For preparing chlorine dioxide, a system using methanol for chlorate reduction has been introduced. It generates little chlorine as a by-product. The measured concentration of $\mathrm{Cl}_{2}$ is $0.045 \mathrm{~g} / \mathrm{l}$ to have $10.0 \mathrm{~g}$ of $\mathrm{ClO}_{2}$ per liter as active chlorine. The designed reaction conditions for each stage are shown in Table 1.

The amount of raw water used in the mill was about $90000 \mathrm{~m}^{3} /$ day. Even if pulp and paper productions are augmented, one of the principles for mill modernization is to suppress water usage to discharge less energy and raw materials into the effluent. Minimizing the biological oxygen demand (BOD) load is also an important principle.

A new effluent treatment system was added to the two existing systems. The new system consists of a closed-type activated sludge treatment using pure oxygen aeration. Mill effluent flows into these activated sludge systems, after which it is treated by high-speed sedimentation, where aluminum sulfate (alum) and anion polymer are used as flocculants. The alum plays the role of an inorganic precipitant; it also decolorizes the effluent by forming insoluble aluminum compounds with the soluble lignin.

Method and quantitation limit for dioxins analysis

Japan Industrial Standard (JIS) K0312 was accepted in 1999 regarding the methods of measuring dioxins and coplanar PCBs in industrial water and mill wastewater. Analyses were carried out according to JIS K0312 and certified by an authorized analysis company (Environment Control Center). In JIS K0312 the detection limit of gas chromatography/mass spectrometry (GC-MS) is $0.1 \mathrm{pg}$ for tetrachlorinated and pentachlorinated compounds, $0.2 \mathrm{pg}$ for hexachlorinated and hepachlorinated compounds, $0.5 \mathrm{pg}$ for octachlorinated compounds, and $0.2 \mathrm{pg}$ or less for coplanar PCBs. The quantitation limit is defined as three times the detection limit.

Approximately 10-251 of wastewater is filtered and then extracted with dichloromethane. Suspended solids separated by the filtration are also extracted in a Soxhlet extractor with toluene, and the extracts are then combined. After addition of standard compounds and clean-up, PCDDs and PCDFs in $50 \%$ dichloromethane/ $n$-hexane are concen-

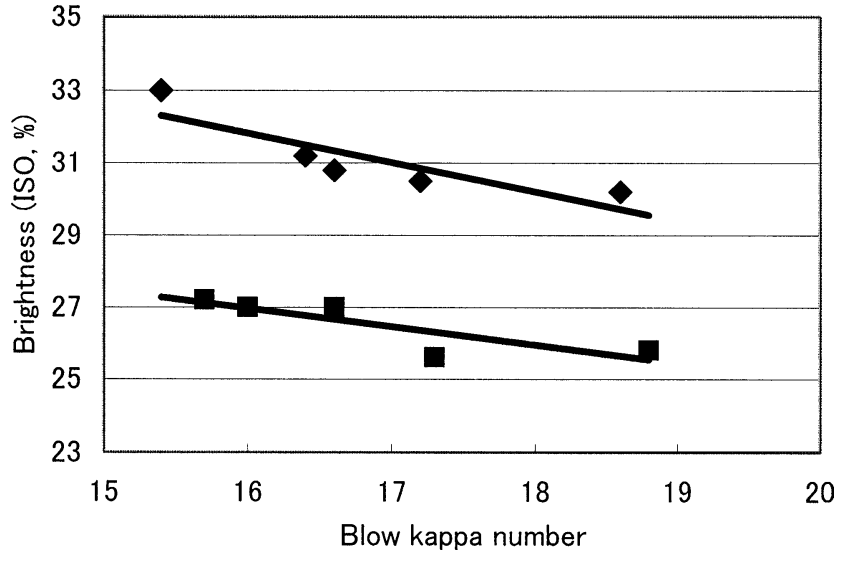

Fig. 1. Relation between the blow kappa number and brightness. Diamonds, extended cooking; squares, conventional cooking

trated to $10-50 \mu \mathrm{l}$. About $1 \mu \mathrm{l}$ of the $10-50 \mu \mathrm{l}$ sample is injected into the GC-MS. Coplanar PCBs are independently analyzed in a similar way using different GC-MS conditions.

The GC-MS conditions are as follows. The equipment included HP6890 and a Micromass AutoSpec-Ultima. The GC conditions for PCDDs and PCDFs were as follows: injection temperature $280^{\circ} \mathrm{C}$, column temperature (1) DB-5 or SP-2331: $130^{\circ} \mathrm{C}$, hold for $2 \mathrm{~min}, 30^{\circ} \mathrm{C} / \mathrm{min}$ to $200^{\circ} \mathrm{C}, 5^{\circ} \mathrm{C} /$ min to $220^{\circ} \mathrm{C}$, hold for $16 \mathrm{~min}, 6^{\circ} \mathrm{C} / \mathrm{min}$ to $300^{\circ} \mathrm{C}$, hold for $13 \mathrm{~min}$ and (2) DB-17: $130^{\circ} \mathrm{C}$, hold for $2 \mathrm{~min}, 30^{\circ} \mathrm{C} / \mathrm{min}$ to $200^{\circ} \mathrm{C}, 3^{\circ} \mathrm{C} / \mathrm{min}$ to $280^{\circ} \mathrm{C}$, hold for $36 \mathrm{~min}$.

The GC conditions for coplanar PCBs were as follows: injection temperature $280^{\circ} \mathrm{C}$, column temperature HT-8, $120^{\circ} \mathrm{C}$, hold for $5 \mathrm{~min}, 15^{\circ} \mathrm{C} / \mathrm{min}$ to $210^{\circ} \mathrm{C}, 2.5^{\circ} \mathrm{C} / \mathrm{min}$ to $250^{\circ} \mathrm{C}, 10^{\circ} \mathrm{C} / \mathrm{min}$ to $300^{\circ} \mathrm{C}$, hold for $13 \mathrm{~min}$.

\section{Results and discussion}

Effect of extended cooking and oxygen delignification

Compared with conventional cooking, delignification selectivity in kappa number and viscosity has been obviously improved for the extended cooking. The extended cooking process shows high viscosities at a given kappa number by approximately 4 points. Thus, the kappa number can be reduced by approximately 1.5 points to achieve the same viscosity as with conventional cooking. As a result, a 16-18 of blow kappa number has been achieved. In addition, the extended cooking process has improved brightness by approximately 4 points at a given kappa number (Fig. 1).

The total efficiency of oxygen delignification is about $45 \%$ ( $36 \%$ for the first stage and $9 \%$ for the second stage). As a result, the kappa number obtained at the final stage was 8-9. Thus, kappa number reduction by oxygen delignification contributes to reducing consumption of bleaching agents and minimizing the effluent impact. 
Table 2. Bleaching results

\begin{tabular}{|c|c|c|c|}
\hline \multirow[t]{2}{*}{ Method } & \multicolumn{2}{|c|}{ Viscosity (cP) } & \multirow{2}{*}{$\begin{array}{l}\text { Final brightness } \\
(\% \text { ISO) }\end{array}$} \\
\hline & Before $\mathrm{O}$ & Final & \\
\hline Conventional & 29.3 & 15.8 & 85.2 \\
\hline $\mathrm{ECF}$ & 33.1 & 21.4 & 85.4 \\
\hline
\end{tabular}

Conventional: OO-C/D-E/O-HD; ECF: OO-D ${ }_{0}-\mathrm{E} / \mathrm{O}-\mathrm{DnD}$

$\mathrm{ClO}_{2}$ dosage: $4 \mathrm{~kg} /$ ton pulp for $\mathrm{D}_{0}$

$\mathrm{ECF}$, elemental chlorine-free bleaching process; $\mathrm{OO}$, two-stage oxygen delignification; $\mathrm{C} / \mathrm{D}$, chlorine and chlorine dioxide treatment; HD, hypochlorite and chlorine dioxide treatment; $\mathrm{DnD}$, chlorine dioxide treatment

Table 3. Water quality of effluent from bleaching process before wastewater treatment

\begin{tabular}{llll} 
Process & $\begin{array}{l}\text { AOX } \\
\text { (kg/ton pulp) }\end{array}$ & $\begin{array}{l}\text { Chloroform } \\
\text { (g/ton pulp) }\end{array}$ & $\begin{array}{l}\text { CODcr } \\
\text { (kg/ton pulp) }\end{array}$ \\
\hline Conventional & 2.39 & 143 & 30.1 \\
ECF & 0.14 & 0.38 & 12.8 \\
\hline
\end{tabular}

$\overline{\mathrm{AOX}}$, adsorbable organic halogen; $\mathrm{COD}_{\mathrm{cr}}$, chemical oxygen demand dichromate method

Table 4. Water quality of mill effluent after wastewater treatment

\begin{tabular}{lllc}
\hline Process & $\begin{array}{l}\text { AOX } \\
(\mathrm{kg} / \text { ton pulp) }\end{array}$ & $\begin{array}{l}\text { Color (Pt-Co) } \\
(\mathrm{mg} / \mathrm{l})\end{array}$ & $\begin{array}{c}\mathrm{BOD}_{5} \\
(\mathrm{mg} / \mathrm{l})\end{array}$ \\
\hline Conventional & 0.58 & 150 & 10 \\
ECF & 0.04 & 50 & 5 \\
\hline
\end{tabular}

Pt-Co, platinum-cobalt method; $\mathrm{BOD}_{5}$, biological oxygen demand

\section{Effect of ECF bleaching}

The pulp viscosity before oxygen delignification for ECF bleaching has been higher than that for conventional bleaching by approximately 4 points (Table 2 ). It makes the process more efficient by extended cooking. The final viscosity is improved by approximately 5 points owing to substitution of hypochlorite $(\mathrm{H})$ with chlorine dioxide.

Improvement of effluent qualities

The capacity of pulp production has increased by $50 \%$, from 1200 to 1800 tons/day. However, because of the waterclosed system in the new ECF pulp plant, the increase in water consumption was successfully suppressed by only $10000 \mathrm{~m}^{3} /$ day. Furthermore, effluent parameters have improved by the effects of ECF bleaching despite the increased pulp and paper production. As demonstrated in Table 3, the amount of pollutant in the sewers of the ECF bleaching plant is markedly reduced compared to that seen with conventional bleaching.

Although adsorbable organic halogen (AOX) is $0.14 \mathrm{~kg} /$ ton of pulp in the sewers with the ECF bleaching process, it is removed by the wastewater treatment. With the ECF process, AOX in the outlet effluent after treatment is $0.04 \mathrm{~kg} /$ ton of pulp (Table 4). In addition, the effluent color was markedly improved. The color level measured by a platinum-cobalt method was $150 \mathrm{mg} / \mathrm{l}$ for conventional
Table 5. Amounts of 2,3,7,8-TCDD and 2,3,7,8-TCDF in ECF bleaching process sewers

\begin{tabular}{lll}
\hline Parameter & $\begin{array}{l}2,3,7,8-\mathrm{TCDD} \\
(\mathrm{pg} / \mathrm{l})\end{array}$ & $\begin{array}{l}2,3,7,8-\mathrm{TCDF} \\
(\mathrm{pg} / \mathrm{l})\end{array}$ \\
\hline $\begin{array}{ll}\text { New ECF line (May 2000) } \\
\mathrm{D}_{0}\end{array}$ & $\mathrm{ND}$ & 0.10 \\
$\quad \mathrm{~N} / \mathrm{P}$ & $\mathrm{ND}$ \\
Rebuilt ECF line & & \\
$\quad$ May 2000 & $\mathrm{ND}$ & 0.39 \\
$\quad \mathrm{D}_{0}$ & $\mathrm{ND}$ & 0.50 \\
$\quad$ E/P & & \\
October 2000 & $(0.04)$ & 0.10 \\
$\quad \mathrm{D}_{0}$ & $(0.06)$ & 0.37 \\
$\quad$ E/P & & \\
Conventional line before being & & \\
$\quad$ rebuilt (February 2000) & $\mathrm{ND}$ & 0.6 \\
$\mathrm{C} \quad$ & 0.8 & 2.2 \\
E/O &
\end{tabular}

Numbers in parentheses represent these below the quantitation limits and above the detection limits

$\mathrm{C}$, chlorine treatment; ND, not detected (under the detection limit)

bleaching. It improved to $50 \mathrm{mg} / \mathrm{l}$ in the new ECF plant, which is almost colorless. Because the sewers became clear, the use of alum and polymer flocculant was reduced.

The odoriferous effluent was also treated by the new system. That is, a closed-type activated sludge treatment system using pure oxygen aeration was in use, causing the odor to be markedly reduced.

Dioxin content of ECF bleaching process sewers

The conventional bleaching line $(\mathrm{OO}-\mathrm{C} / \mathrm{D}-\mathrm{E} / \mathrm{O}-\mathrm{HD})$ was rebuilt as the other ECF line $\left(\mathrm{OO}-\mathrm{D}_{0}-\mathrm{E} / \mathrm{P}-\mathrm{D}\right)$ in February 2000. Table 5 shows values for 2,3,7,8-TCDD and 2,3,7,8TCDF in the sewers of the two ECF bleaching lines prior to the wastewater treatment process as well as those of the conventional bleaching run. The items shown in Table 5 have high toxicity among the dioxins found in the wastewater: The TEFs for 2,3,7,8-TCDD and 2,3,7,8-TCDF were 1.0 and 0.1 , respectively. The data have not been converted to TEQ but, rather, are expressed as the actual concentrations in picograms per liter.

The 2,3,7,8-TCDD concentration has been nearly undetectable for the $\mathrm{C}$ stage of the conventional process or the $\mathrm{D}_{0}$ stage of the rebuilt ECF process. However, during the alkali stage following them, it was $0.8 \mathrm{pg} / \mathrm{l}$ for the conventional method but was reduced to $0.06 \mathrm{pg} / \mathrm{l}$ or less for the $\mathrm{E} / \mathrm{P}$ stage of the rebuilt ECF process. A new ECF line also demonstrates no detected 2,3,7,8-TCDD. As for $2,3,7,8$-TCDF, the concentration has been markedly reduced during the alkali stage as a result of the conversion to ECF bleaching. That is, the value for the E/P stage of the ECF line was reduced to $0.50 \mathrm{pg} / 1$ or less, whereas that for the E/O stage before rebuilding was $2.2 \mathrm{pg} / \mathrm{l}$.

Table 6 shows the analysis results for the total dioxins in the ECF sewers prior to the wastewater treatment process. Data are the cumulative values after adding the TEQs for PCDDs, PCDFs, and coplanar PCBs together as the total 
Table 6. Total dioxin (PCDDs + PCDFs + coplanar PCBs) contents of bleaching process sewers

\begin{tabular}{llll}
\hline Parameter & \multirow{2}{*}{$\begin{array}{l}\text { New ECF line } \\
\text { (May 2000) }\end{array}$} & \multicolumn{2}{l}{ Rebuilt ECF line } \\
\cline { 3 - 4 } & & May 2000 & October 2000 \\
\hline $\mathrm{D}_{0}$ & 0.063 & 0.074 & 0.084 \\
$\mathrm{E} / \mathrm{P}$ & 0.14 & 0.29 & 0.18 \\
\hline
\end{tabular}

Results are given in pg TEQ/1

TEQ. To achieve the cumulative values, each amount less than the quantitation limit was converted to zero. All of the dioxin concentrations measured in the bleaching process sewers were below the environmental standard of $1 \mathrm{pg}$ TEQ/l.

The present survey demonstrates that wastewater emerging directly from the ECF bleaching process has had a dioxin concentration of less than $1 \mathrm{pg} T E Q / 1$, the environmental standard, since the bleaching facilities of the mill undertook various measures, including strengthening the pulp cleaning process prior to bleaching and introducing oxygen delignification. Moreover, the values for 2,3,7,8TCDD and 2,3,7,8-TCDF are sufficiently lower than the $10 \mathrm{pg} / \mathrm{l}$ value suggested by the U.S. cluster rule as the minimum level of analysis. ${ }^{7}$ In addition to these conclusions, the present survey makes clear that conversion to an ECF bleaching process, in which no chlorine $\left(\mathrm{Cl}_{2}\right.$ or $\left.\mathrm{NaClO}\right)$ is used, results in even further reductions of both 2,3,7,8TCDD and 2,3,7,8-TCDF, which are two of the most highly toxic dioxins.

Dioxins as impurities of herbicides in pulp and bleaching mill sewer

An agrochemical such as chloronitrofen (CNP) made from chlorinated phenols had been scattered in paddy rice fields as a herbicide. It has been clarified that CNP includes 1,3,6,8- and 1,3,7,9-TCDDs and 2,4,6,8-TCDF. ${ }^{14}$ The TEFs for the three compounds are not yet defined by $\mathrm{WHO}^{1998}$, and their concentrations do not consist of the total TEQ. Some studies found that concentrations of $1,3,6,8-$ and 1,3,7,9-TCDDs in effluents from kraft pulp beaching plants are relatively high (e.g., $440 \mathrm{pg} / \mathrm{l}$ for $1,3,6,8$-TCDD) ${ }^{15}$ On the other hand, the TEFs for 1,2,3,6,7,8- and 1,2,3,7,8,9HxCDDs are defined as 0.1. Therefore, the total TEQs of the effluent may increase if they might be formed by chlorination of 1,3,6,8- and 1,3,7,9-TCDDs. Data obtained from the surveyed mill in October 1999 are shown in Table 7. The 1,3,6,8- and 1,3,7,9-TCDDs were detected in both raw water and process water. The 1,2,3,6,7,8- and 1,2,3,7,8,9-HxCDDs were not detected.

It has been suggested that use of chlorophenolic wood preservatives by lumber processors was the main source of high chlorinated PCDD/Fs throughout the systems based on patterns of trace PCDFs in egg samples and significant correlations between egg concentrations of pentachlorophenol and both heptachlorodibenzo- $p$-dioxins
Table 7. Congener profile of PCDDs and PCDFs in the process water of ECF lines

\begin{tabular}{|c|c|c|c|}
\hline Dioxins & Raw water & $\mathrm{D}_{0}$ & $\mathrm{E} / \mathrm{O}$ \\
\hline 1,3,6,8-TCDD (pg/l) & 3.9 & 5.1 & 57 \\
\hline $1,3,7,9-\mathrm{TCDD}(\mathrm{pg} / \mathrm{l})$ & 1.0 & 3.0 & 32 \\
\hline 2,3,7,8-TCDD (pg/l) & ND & ND & ND \\
\hline $1,2,3,7,8-\operatorname{PnCDD}(\mathrm{pg} / \mathrm{l})$ & ND & ND & ND \\
\hline $1,2,3,4,7,8-\mathrm{HxCDD}(\mathrm{pg} / \mathrm{l})$ & ND & ND & ND \\
\hline $1,2,3,6,7,8-\mathrm{HxCDD}(\mathrm{pg} / \mathrm{l})$ & ND & ND & ND \\
\hline 1,2,3,7,8,9-HxCDD (pg/1) & ND & ND & ND \\
\hline $1,2,3,4,6,7,8-\mathrm{HpCDD}(\mathrm{pg} / \mathrm{l})$ & 0.63 & 0.84 & 1.2 \\
\hline $\mathrm{OCDD}(\mathrm{pg} / \mathrm{l})$ & 2.0 & 1.7 & 7.7 \\
\hline $1,2,7,8-\mathrm{TCDF}(\mathrm{pg} / \mathrm{l})$ & ND & 0.32 & 0.29 \\
\hline $2,3,7,8-\mathrm{TCDF}(\mathrm{pg} / \mathrm{l})$ & ND & 0.28 & 0.41 \\
\hline 1,2,3,7,8-PnCDF (pg/l) & 0.21 & ND & ND \\
\hline $2,3,4,7,8-\operatorname{PnCDF}(\mathrm{pg} / \mathrm{l})$ & ND & ND & ND \\
\hline HxCDFs (pg/l) & ND & ND & ND \\
\hline $1,2,3,4,6,7,8-\mathrm{HpCDF}(\mathrm{pg} / \mathrm{l})$ & 0.62 & 0.58 & 0.32 \\
\hline $1,2,3,4,7,8,9-\mathrm{HpCDF}(\mathrm{pg} / \mathrm{l})$ & ND & ND & ND \\
\hline OCDF (pg/l) & ND & ND & ND \\
\hline
\end{tabular}

(HpCDDs) and octachlorodibenzo- $p$-dioxin (OCDD). ${ }^{12}$ Moreover, despite a reduction in PCDD/Fs, the estimated TEQs remained elevated throughout the 1980s in some urban colonies due to contributions from PCBs. ${ }^{13}$ Therefore, examination of the dioxins (PCDD/Fs and coplanar PCBs) pattern and levels in ECF bleaching mill sewers continues from the aspect of environmental water quality.

\section{Conclusions}

The present survey of dioxins demonstrates that wastewater emerging directly from the ECF bleaching process has had a dioxin concentration of less than $1 \mathrm{pg}$ TEQ/l (the environmental standard) since the mill undertook various measures that included strengthening the pulp cleaning process prior to bleaching and introducing oxygen delignification. The 1,3,6,8- and 1,3,7,9-TCDDs from a herbicide were detected in both raw water and the process water. Therefore, examination of the dioxin pattern and their levels in ECF bleaching mill sewers continues from the aspect of environmental water quality. Pollutant amounts in the effluent from the ECF bleaching plant are markedly reduced compared with conventional chlorine bleaching. AOX is further reduced to $0.04 \mathrm{~kg} / \mathrm{ton}$ pulp by the effluent treatment. The color of the outlet effluent improved to $50 \mathrm{mg} / \mathrm{l}$ with the ECF operation.

Acknowledgment Keiichi Nakamata is a Guest Scientist at the Center for Tsukuba Advanced Research Alliance, University of Tsukuba, Ibaraki 305-8572, Japan

\section{References}

1. Berry RM, Fleming BI, Voss RH, Luthe CE, Wrist PE (1989) Toward preventing the formation of dioxins during chemical pulp bleaching. Pulp Paper Canada 90:T279-T289

2. Crawford RJ, Stryker MN (1988) Factors that affect the generation of chloroform in bleaching. TAPPI J 71(11):151-159 
3. Special committee for dioxin measures of Japan Paper Association (1999) Result of dioxin prevention measures of pulp and paper industries in Japan (in Japanese). Jpn TAPPI 53:67-72

4. Meshitsuka G (2001) Pulp and paper industry and dioxins problem (in Japanese). Jpn J Pap Technol 44(6):1-4

5. Ohi H (2000) Dioxins regulations and pulp bleaching (in Japanese). Jpn J Pap Technol 43(6):1-6

6. Berry RM (1996) Pulp bleaching and the environment: dioxins and furans in effluents, pulp, and solid waste. In: Dence CV, Reeve DW (eds) Pulp bleaching, principles and practice. TAPPI, Atlanta, pp 799-820

7. Wiegand P, Thacker W, Miner R (1999) Effluent quality at kraft mills that use complete substitution bleaching. TAPPI J 82(4):135144

8. Engwall M, Broman D, Dencker L, Naf C, Zebuhr Y, Runstrom B (1997) Toxic potencies of extracts of sediment and settling particulate matter collected in the recipient of a bleached pulp mill effluent before and after abandoning chlorine bleaching. Environ Toxicol Chem 16:1187-1194

9. Kemeny TE, Banerjee S (1997) Relationships among effluent constituents in bleached kraft pulp mills. Water Res 31:15891594

10. Macdonald RW, Ikonomou MG, Paton DW (1998) Historical inputs of PCDDs, PCDFs, and PCBs to a British Columbia interior lake: the effect of environmental controls on pulp mill emissions. Environ Sci Technol 32:331-337

11. Elliott JE, Martin PA (1998) Chlorinated hydrocarbon contaminants in grebes and seaducks wintering on the coast of British Columbia, Canada: 1988-1993. Environ Monit Assess 53:337-362

12. Elliott JE, Machmer MM, Henny CJ, Wilson LK, Norstrom RJ (1998) Contaminants in ospreys from the Pacific Northwest. I. Trends and patterns in polychlorinated dibenzo- $p$-dioxins and -dibenzofurans in eggs and plasma. Arch Environ Contam Toxicol 35:620-631

13. Elliott JE, Harris ML, Wilson LK, Whitehead PE, Norstrom RJ (2001) Monitoring temporal and spatial trends in polychlorinated dibenzo- $p$-dioxins (PCDDs) and dibenzofurans (PCDFs) in eggs of great blue heron (Ardea herodias) on the coast of British Columbia, Canada, 1983-1998. Ambio 30:416-428

14. Yamagishi T, Miyazaki T, Akiyama K, Morita M, Nakagawa J, Horii S, Kaneko S (1981) Polychlorinated dibenzo-p-dioxins and dibenzofurans in commercial diphenyl ether herbicides, and in freshwater fish collected from the application area. Chemosphere 10:1137-1144

15. Ohi $\mathrm{H}$ (2002) Dioxins levels in chlorine dioxide bleaching of hardwood oxygen-bleached kraft pulp. II. Levels before and after mill operation of chlorine dioxide bleaching (in Japanese). Jpn TAPPI 56:1325-1334 